\title{
Mitigation of ammonia emissions from pig production using reduced dietary crude protein with amino acid supplementation
}

\author{
Shule Liu ${ }^{1}$, Ji-Qin Ni ${ }^{1}{ }^{1}$, John S. Radcliffe ${ }^{2}$, Caitlin E. Vonderohe ${ }^{2}$ \\ ${ }^{1}$ Department of Agricultural and Biological Engineering, \\ Purdue University, West Lafayette, IN 47907, USA \\ ${ }^{2}$ Department of Animal Sciences, Purdue University, West Lafayette, IN 47907, USA \\ * Corresponding author. Tel.: +1 (765) 469 1733. E-mail address: jiqin @ purdue.edu (J.-Q. Ni)
}

\begin{abstract}
To mitigate ammonia $\left(\mathrm{NH}_{3}\right)$ emissions from pig production and understand the dynamic emission profiles, reduced dietary crude protein $(\mathrm{CP})$ with amino acid supplementation was studied with 720 pigs in a 12-room research building for 155 days that covered from weaned to finishing stages. The pigs were divided into three 4-room groups and fed with $2.1 \%-3.8 \%$ reduced $\mathrm{CP}\left(\mathrm{T}_{1}\right), 4.4-7.8 \%$ reduced $\mathrm{CP}\left(\mathrm{T}_{2}\right)$, and standard (control) diets, respectively. Compared with the control group, $\mathrm{T}_{1}$ and $\mathrm{T}_{2}$ decreased manure volumes and manure $\mathrm{NH}_{4}{ }^{+}-\mathrm{N}$ contents. Group-mean $\mathrm{NH}_{3}$ emission from the control group was $68.9 \mathrm{~g} \mathrm{~d}^{-1}$ $\mathrm{AU}^{-1}(\mathrm{AU}=500 \mathrm{~kg}$ live mass $)$. Emissions from $\mathrm{T}_{1}\left(46.7 \mathrm{~g} \mathrm{~d}^{-1} \mathrm{AU}^{-1}\right)$ and $\mathrm{T}_{2}\left(29.8 \mathrm{~g} \mathrm{~d}^{-1} \mathrm{AU}^{-1}\right)$ were reduced by $32.2 \%$ and $56.7 \%(p<0.05)$, respectively. Dynamic peak $\mathrm{NH}_{3}$ emissions appeared during the third nursery phase for $T_{1}$ and $T_{2}$, but delayed to the first grower phase for the control group.

Keywords: Air quality; air pollution abatement; animal feeding operation; dietary manipulation; pig production; pollution control.

\section{Introduction}

Ammonia $\left(\mathrm{NH}_{3}\right)$ emission from animal feeding operation has received increasing attention from the scientific world and regulatory agencies for its potential negative impacts on the environment, ecosystem, and human and animal health. The farms, which house more than a designated number of animals, or of which the emitted $\mathrm{NH}_{3}$ exceed a reportable quantity, are subject to reporting and permitting requirements under the Emergency Planning and Community Right to Know Act (EPCRA) and the Comprehensive
\end{abstract}


Environmental Response, Compensation, and Liability Act (CERCLA) in the United States (EPA, 2009).

Ammonia emitted from animal production originates from either hydrolysis of urea in the urine, or decomposition of nitrogen $(\mathrm{N})$ containing organics in the feces (Aarnink et al., 1995). About $70 \%$ of the $\mathrm{N}$ in the diet could be excreted in urine and feces, a potential $\mathrm{N}$ source of eutrophication in water body if not managed appropriately, and $31 \% \mathrm{~N}$ in the urine and feces could be lost as $\mathrm{NH}_{3}$ emissions during house storage and land application (Aarnink and Verstegen, 2007). Increasing the utilization efficiency of dietary $\mathrm{N}$ and decreasing $\mathrm{N}$ in the excreta is a potential method to reduce $\mathrm{NH}_{3}$ emissions. Therefore, feeding pigs with balanced nutrients has been considered effective in reducing $\mathrm{NH}_{3}$ emissions due to reduced surplus nutrients in the excreta.

Crude protein, composed of amino acids (AA), is the primary source of $\mathrm{N}$ in pigs feed. Pigs do not require $\mathrm{CP}$ in the feed but their nutritional requirements varied substantially to different $\mathrm{AA}$ (Holden and Ensminger, 2006). Among the 10 essential AA that cannot be generated through internal metabolisms of pigs, the most limiting essential AA is Lysine, followed by Tryptophan and Threonine (Holden and Ensminger, 2006). The standard diet of pigs is formulated to meet the demand of Lysine, resulting in excessive intake of other AA by the pigs. If the amount of CP in the diet is reduced by using synthetic AA, there will be significantly less $\mathrm{N}$ excreted by the pigs (Radcliffe et al., 2005). Some studies have been conducted to investigate the effects of feeding pigs with CP-reduced diet on $\mathrm{NH}_{3}$ emission from pig production. Portejoie et al. (2004) found that a decrease in dietary CP from $20 \%$ to $12 \%$ led to a decrease in $\mathrm{NH}_{3}$ emissions by $63 \%$. It was summarized from the previous studies that every $10 \mathrm{~g} \mathrm{~kg}^{-1}$ reduction in CP could lead to $10 \%-12.5 \%$ lower $\mathrm{NH}_{3}$ emissions (Aarnink and Verstegen, 2007).

The reduction of $\mathrm{CP}$ does not necessarily result in inhibited pig growth if commercially available synthetic AA is supplemented with the ratio matching the growth demand of pigs. Reducing CP with sufficient AA supplementation in pig diet showed little impacts on the pig weight gains, despite reduced N retention (Portejoie et al., 2004; Toledo et al., 2014; Zervas and Zijlstra, 2002). Philippe et al. (2006) and Le et al. (2007) reported that supplying sufficient essential AA to the CP-reduced pig diet significantly restrained the $\mathrm{NH}_{3}$ emissions while maintaining the normal performance of pigs. 
Nevertheless, supplying synthetic AA excessively was reported to decrease the feed intake and weight gain of pigs (Edmonds and Baker, 1987).

However, previous studies could not fully reveal the effects of $\mathrm{CP}$ reduction on $\mathrm{NH}_{3}$ emissions during different pig growth stages from weaned to finishing. Most of the field studies were of short-term experiments without covering the sufficiently long growth cycle of pigs. For example, $\mathrm{NH}_{3}$ was observed for only 21 days in a 9-week field monitoring at a swine barn by Canh et al. (1998b). The study of Portejoie et al. (2004) was based on 15 pigs and a 30-day observation. Other studies were carried out with small number of pigs in experimental chambers (e.g., Power et al. 2007; Panetta et al. 2005a), where though the test environment was better controlled, the representativeness could be limited compared with field environment because of the scale effect and the substantial environment differences between in a chamber and a pig production building.

Lack of reliable data and continuous monitoring was another obstacle in the path of revealing the characteristics of $\mathrm{NH}_{3}$ emissions from production of pigs under dietary manipulation. Some researchers (e.g., Hayes et al., 2004; Otto et al., 2003; Portejoie et al., 2004) determined $\mathrm{NH}_{3}$ emissions by discretely quantifying $\mathrm{NH}_{3}$ concentrations with limited number of samples using measurement techniques such as wet chemistry and gas detector tubes, which have relatively low sensitivity and low accuracy compared with high-end $\mathrm{NH}_{3}$ analyzers ( $\mathrm{Ni}$ and Heber, 2008). Because $\mathrm{NH}_{3}$ in animal buildings exhibits profound diel variations (Saha et al., 2014; Ye et al., 2009), a limited number of concentration samples in a day could lead to significant bias in emission calculations.

So far, the dynamic profiles of $\mathrm{NH}_{3}$ emissions from all pig growth stages affected by dietary manipulation are yet to be investigated. Moreover, experiments in controlled environment but closer to the field conditions are needed. The objective of this paper was to uncover the effects of reduced dietary $\mathrm{CP}$ with AA supplementation on $\mathrm{NH}_{3}$ emissions from a swine environmental research building with 720 pigs, covering nursary to finising stages. 


\section{Materials and Methods}

\subsection{Building description}

The swine building is located at the Animal Sciences Research and Education Center, Purdue University, West Lafayette, Indiana. There are 12 rooms in total with six rooms along the south wall and other six along the north wall of the building. Each room measures $11.0 \mathrm{~m} \times 6.1 \mathrm{~m} \times 2.7 \mathrm{~m}(\mathrm{~L} \times \mathrm{W} \times \mathrm{H})$ and is comprised of a pig living space (PLS) above a fully-slatted concrete floor and two under-floor isolated 1.8-m deep manure pits (Figure 1). There are 6 or 12 pens in each PLS that can house 60 finishing pigs.

[Insert Figure 1 here]

Two curtain-covered inlets above the east and west doors of the building allow fresh outdoor air enter into the building. The curtain above the east wall is controlled by a static pressure controller (Model SP-2, Airstream Ventilation Systems, Assumption, IL, USA). The other curtain above the west wall is controlled manually. The extent of the curtain opening is regulated, depending on the outdoor weather condition and the ventilation needs of the rooms.

The outdoor fresh air enters each room through three baffled V-shaped ceiling inlets and a perforated 38-cm diameter PVC air pipe installed $20 \mathrm{~cm}$ below the ceiling and along the room. Room air is exhausted via four direct-driven ventilation fans in each room: two variable-speed pit fans and two singlespeed wall fans. The inlets of the 25-cm diameter pit fans (Model P4E30, Multifan, Bloomington, IL, USA) are connected to two 25.4-cm diameter perforated PVC exhaust air pipe in the pit. The two wall fans are installed side by side on the end wall: one is of 36-cm diameter (Model V4E35, Multifan), and the other is of 51-cm diameter (Model V4E50, Multifan). The measurement and calibration methods for both pit fans and wall fans were described by Ni et al. (2015).

Ventilation in each room is controlled independently with a Fancom controller (Model FCTC, Vancom BV, Panningen, The Netherlands). A propane heater (Model 379K, L.B. White Co. Onalaska, WI, USA) is installed in each room to provide supplementary heat when the room temperature is too low for pigs in winter. Two other propane heaters (Model Guardian 60, L.B. White Co. Onalaska, WI, USA) 
are installed close to the east and west doors of the building to pre-heat the fresh air before it reaches the rooms in cold seasons.

\subsection{Experiment description}

Weaned piglets were moved into R1-R6 on Feb. 25, 2015, and into R7-R12 one week later on Mar. 4, 2015 (Table 1). There were 60 piglets in each room, weighed between 4.5 and $13.0 \mathrm{~kg}$ each at the beginning of the experiment. Pigs were fed based on their growth demand during the three production stages: nursery (from weaned to $25 \mathrm{~kg}$ ), grower (25-70 kg), and finisher (70 $\mathrm{kg}$ to market). The duration of the nursery and grower stages lasted for $43 \mathrm{~d}$ and $63 \mathrm{~d}$, respectively. The duration of the finisher stage lasted for $34 \mathrm{~d}$ in R4-R6 and R10-R12; and $41 \mathrm{~d}$ in R1-R3 and R7-R9.

[Insert Table 1 here]

The pig diet was based on yellow dent corn $(7.5 \% \mathrm{CP})$, soybean meal $(47.5 \% \mathrm{CP})$, corn DDGS (Distillers Dried Grains with Solubles,7\%, 30.9\% CP), limestone, mono-calcium phosphate, salt, choice whitle grease, trace mineral premix, vitamin premix, phytase, Se premix, and Lincomix. The diet was also supplemented with essential AA, including L-lysine HCl, L-threonine, L-tryptophan, DL-methionine, Lvaline, and L-isoleucine. The ingredients of pig diet, including the type and quantity of supplementary AA, changed upon pig dietary demands at different growth stages (Table 2). The percentage of the soybean meal increased throughout the four phases of the nursery stage and decreased until the last finisher phase, when it profoundly increased. That of the corns increased throughout the experiment until the last finisher phase, when it decreased slightly.

\section{[Insert Table 2 here]}

There were three groups of pigs in the 12 rooms based on the amount of $\mathrm{CP}$ in the feed: Control, Treated $1\left(\mathrm{~T}_{1}\right)$, and Treated $2\left(\mathrm{~T}_{2}\right)$. Each group had four replicated rooms: control group included R1, R4, R8, and R11; $\mathrm{T}_{1}$ group included R2, R5, R9 and R10; $\mathrm{T}_{2}$ group included R3, R6, R7 and R12 (Table 1). The control group was fed with standard diet. The two treated groups, $\mathrm{T}_{1}$ and $\mathrm{T}_{2}$, were supplied with 2.1$3.8 \%$ and $4.4-7.8 \% \mathrm{CP}$ reduced diet, respectively. To ensure sufficient essential AA in the diet, synthetic 
AA was supplied increasingly from control to the $T_{2}$ group (Table 2).

\subsection{Pig and manure}

The pigs were weighed individually at both the beginning and the end of the experiment, as well as at the end of each growth stage. Pig numbers in each room were also recorded whenever there were reductions.

Weekly increments of manure volumes in the under-floor pits were calculated by multiplying the manure pit area $\left(67.08 \mathrm{~m}^{2}\right.$ for the two pits in each room) by the differences of manure depths, which were obtained by subtracting the manure headspace heights from the pit depth. The manure headspace heights were measured weekly using a Laser Distance Meter (Model Leica Disto Special-5, Leica Geosystems Inc., Norcross, GA). Accumulated volumes of manure production was the summations of the weekly manure increments in the same room.

Four vacuum manure column samples were taken in each room in three growth stages. Those from the same room were pooled and mixed for analyzing concentrations of ammonium nitrogen $\left(\mathrm{NH}_{4}{ }^{+}-\mathrm{N}\right)$ and other variables (included dry matter, ash, phosphorus, and total nitrogen), which will be reported elsewhere. Manure $\mathrm{NH}_{4}{ }^{+}-\mathrm{N}$ concentrations were measured using the Kjeldahl procedure (Nelson and Sommers, 1972).

\subsection{Air quality monitoring}

The swine building was equipped with a comprehensive air quality online monitoring system, which included analyzers for gas concentration measurement, and sensors for fan operation and airflow rate monitoring, and indoor environment monitoring.

\subsubsection{Air sampling and gas concentration measurement}

There was a total of 25 air sampling locations (ASLs) in the building. One of the ASLs was installed in the building hallway to sample room inlet air. The other 24 ASLs were distributed in the 12 rooms, two in each room: one at $120 \mathrm{~cm}$ from the inlet of the $36-\mathrm{cm}$ wall fan to sample exhausting room air and the other inside the inlet pipe of the pit fans to sample exhausting manure headspace air. Air samples were collected for $20 \mathrm{~min}$ at the inlet ASL and $10 \mathrm{~min}$ at other ASLs, switching from one to the other. From 
February 25 to April 18, air samples were switched among the 12 pit ASLs and the inlet air, because only pit fans were in use during this period. Starting from April 19 to July 30, when all the wall fans were turned on, air sampling at the 12 wall fans were activated.

Ammonia concentrations in the sampling air were measured continuously using an Innova photoacoustic infrared multi-gas monitor (Model 1412, LumaSense Technologies, Ballerup, Denmark). Certified zero air and span $\mathrm{NH}_{3}$ gas (49.2 ppm) were used to check the precision of the gas analyzer weekly. The precision, expressed as relative standard deviation (RSD), was $4 \%$ throughout this experiment.

\subsubsection{Ventilation monitoring}

The operational status of each of the 24 wall fans was monitored. The AC voltage to each wall fan was converted to DC voltages and recorded. The static pressures between each room and its outside end wall where the wall fans were installed were measured using a differential pressure transducer (M260, Setra System, Boxborough, MA). A linear model (ventilation rate vs. static pressure) was established for each wall fan during two fan calibration sessions before and after the experiment. A detailed description of this method was published by Ni et al. (2015).

Ventilation rates of the pit fans were measured directly using an innovative Pit Exhaust Airflow Measurement Assembly (PEAMA), of which the output unit was in air volume per unit of time. The PEAMA was composed of a PVC pipe (914-mm long, 300-mm ID, and 305-mm OD), a 610-mm long flow straightener, and an anemometer (Ni et al., 2016). The anemometers (Model 27106RS, R. M. Young, Traverse City, MI, USA) were calibrated in the lab before and after the experiment.

\subsubsection{Other measurements}

Air temperatures at all ASLs were measured with T-type thermocouples. The air temperature data were used to convert volumetric $\mathrm{NH}_{3}$ concentration in $\mathrm{ppm}$ to mass concentration in $\mathrm{mg} \mathrm{m}^{-3}$ for emission calculation. Relative humidity (RH) transmitters (Model HX92BC, Omega, Atlanta, GA, USA) were installed in selected rooms (R1, R2, R3, and R11). Passive Infrared Detector (PID) motion sensors (Model SRN-2000 Detector, Visonic Inc., Bloomfield, CT, USA) were installed on the end wall of each 
room, $2.2 \mathrm{~m}$ above the floor and tilted downward at $15^{\circ}$, to monitor the pig activities. The RH and activity data were used for experiment quality control.

\subsubsection{Data acquisition, signal processing, and air sampling control}

The multi-gas monitor and all online sensors were connected to an on-site computer system (OSCS) for data acquisition and signal processing. The OSCS consisted of a PC, data acquisition hardware, and custom-developed software AirDAC (Ni and Heber, 2010). Analog or digital output signals from the monitor and sensors were acquired at $1 \mathrm{~Hz}$, converted to data in engineering units, then averaged over 15sec and 1-min intervals and saved in two separate AirDAC data files. At 2:00 AM each day, measurement data from the previous day were automatically pre-processed to generate data statistics and graphs in an Excel file that was delivered to researchers via an automatic email. The OSCS also automatically controlled air sampling locations, time duration at each location, and sequence of different locations.

\subsubsection{Data processing}

Collected raw data were processed using custom software CAPECAB (Fibre Recovery Systems, Inc., Calgary, AB, Canada). After data were imported into CAPECAB, they went through a validation process. Raw data were plotted and subject to visual inspection. Invalid data due to the sensor and other errors were removed after being confirmed with the experiment field note. Validated data were corrected when necessary based on instrument and sensor calibrations. Data of manure volume, pig number, pig weight, and $\mathrm{NH}_{3}$ concentration at individual locations were interpolated in the CAPECAB, to match the other measurement, including ventilation and environmental variables.

Because $\mathrm{NH}_{3}$ concentrations at multiple locations were measured using the location-shared gas monitor, there was a transition time when switching from one location to another. During data processing, only the last 3 min of $\mathrm{NH}_{3}$ concentration data during the 10- and 20-min sampling time were extracted and used. Data during the 7 and 17 min transition time at the beginning of line switching was excluded.

Ventilation rates of the 24 pit fans were calculated real-time in the OSCS. Ventilation rates of the 24 wall fans were calculated during post-measurement data processing using the fan operation time and fan models, in which the ventilation rate was a function of the measured static pressure across the end wall 
and the fan power supply voltage. The models were developed during on-site wall fan testing (Ni et al. 2015).

The unit of measured $\mathrm{NH}_{3}$ concentrations in ppm was converted to $\mathrm{mg} \mathrm{m}^{-3}$ using the ideal gas law before $\mathrm{NH}_{3}$ emission rate calculation. Ammonia emission rate for each room at a given minute was calculated with Eq. (1).

$$
E_{i}=\left(C_{i, p}-C_{\text {iltet }}\right) \times V_{i, p}+\left(C_{i, w}-C_{\text {intet }}\right) \times V_{i, \mathrm{w}}
$$

where $E_{i}$ is $\mathrm{NH}_{3}$ emission rate from $i^{\text {th }}$ room, $\mathrm{mg} \mathrm{min}^{-1} ; C_{i, p}$ and $C_{i, w}$ are $\mathrm{NH}_{3}$ concentrations at the pit fan exhaust and wall fan exhaust, respectively, of the $i^{\text {th }}$ room, $\mathrm{mg} \mathrm{m}^{-3} ; C_{\text {inlet }}$ is $\mathrm{NH}_{3}$ concentration at the room inlet, $\mathrm{mg} \mathrm{m}^{-3} ; V_{i, p}$ and $V_{i, w}$ are ventilation rates of the two pit fans and two wall fans, respectively, in $i^{\text {th }}$ room, $\mathrm{m}^{3} \mathrm{~min}^{-1}$.

The 1-min data of $\mathrm{NH}_{3}$ emission rates were used to obtain sample means and daily means. The phase, stage, and cycle means were calculated by averaging the daily means over the phase, stage or cycle, respectively, for individual rooms, test group of 4 rooms, and entire building of 12 rooms (Table 3). Standard deviations and statistic tests were also calculated on daily means with relevant room coverage. The ANOVA (analysis of variance) analysis was applied to test the effects of dietary treatment on the $\mathrm{NH}_{3}$ emissions by using the proc anova in the software SAS 9.4 (SAS Institute Inc., Cary, NC).

\section{[Insert Table 3]}

\section{Results}

\subsection{Room environmental condition}

\subsubsection{Temperature}

The phase mean outdoor temperature increased throughout the experiment (Figure 2, bottom). From $\mathrm{N} 1$ to $\mathrm{G} 1$ periods, the phase mean outdoor temperature increased from $-7.4^{\circ} \mathrm{C}$ to $11.7^{\circ} \mathrm{C}$, and the propane heaters in the rooms were in use to maintain optimal temperatures and supply sufficient heat for the growth pigliets. Complete shut-off of the heaters began from phase G2 when the phase mean outdoor temperature reached $19.3^{\circ} \mathrm{C}$. It continued to increased and reached $24.3{ }^{\circ} \mathrm{C}$ by the phase $\mathrm{F} 2$. 
From phase N1 to N4, the building phase mean temperature increased from 22.8 to $23.9^{\circ} \mathrm{C}$ in the pits but decreased from 33.2 to $25.2^{\circ} \mathrm{C}$ in the PLS. The temperatures measured in the PLS were higher than those in the pit during the nursery period when the heaters were in use in all rooms. During the grower and finisher stages, the building phase mean temperatures in the pits and the PLS were close to each other, and both increased towards the end of the cycle. From phase G1 to F2, the building phase mean temperatures increased from $22.1^{\circ} \mathrm{C}$ to $26.0^{\circ} \mathrm{C}$ in the pits and from $23.5^{\circ} \mathrm{C}$ to $25.5^{\circ} \mathrm{C}$ in the PLS.

Throughout the experiment, the group cycle means of pit temperatures were the same for the $T_{1}$ and $\mathrm{T}_{2}$ groups (both $23.8 \pm 2.0^{\circ} \mathrm{C}$ ), but slightly lower than that in the control group $\left(24.1 \pm 2.1^{\circ} \mathrm{C}\right)$. There were no significant differences in the group cycle means of the PLS temperatures $(p>0.05)$.

[Insert Figure 2 here]

\subsubsection{Ventilation}

The pit fans were kept on throughout the experiment. The building phase mean pit fan ventilation rates averaged at 24.9 and $27.4 \mathrm{~m}^{3} \mathrm{~min}^{-1}$ for the first two phases $\mathrm{N} 1$ and $\mathrm{N} 2$, and increased to $41.9 \mathrm{~m}^{3}$ $\min ^{-1}$ by the end of the nursery stage (Figure 3, top). It was an essential measure to provide minimum ventilation rate during very cold days, preventing the substantial decrease of room temperature and removing extra airborne pollutants and moisture from the room. The pit ventilation rate maintained maximum performance during the grower and finisher stages, ranging from 41.9 to $49.7 \mathrm{~m}^{3} \mathrm{~min}^{-1}$. The group phase mean of pit ventilation rate for the control group was higher than that for the two treated groups from phase N1 to G1, but they were of the same level for the rest of the time.

The wall fans were kept off during the nursery stage. They were off for most of the time but turned on occasionally during phases G1 and G2, providing building phase mean ventilation rates of $9.8 \pm 19.8$ and $73.2 \pm 43.8 \mathrm{~m}^{3} \mathrm{~min}^{-1}$, respectively. The wall fans were in full performance since G3 when the sensible heat was accumulated rapidly in the rooms, and timely removal of the heat was required to keep a moderate indoor environment. The building phase mean ventilation rate reached $114.0 \mathrm{~m}^{3} \mathrm{~min}^{-1}$ by phase G3, and maintained maximum performance during the finisher stage. It was 125.1 and $126.5 \mathrm{~m}^{3} \mathrm{~min}^{-1}$, respectively, during F1 and F2. 
The group cycle mean of total ventilation rates of the control, $\mathrm{T}_{1}$, and $\mathrm{T}_{2}$ groups were $109.5 \pm 62.7$, $110.9 \pm 64.8,109.4 \pm 65.9 \mathrm{~m}^{3} \mathrm{~min}^{-1}$, respectively. From phase N1 to G1, the group phase mean of the total ventilation rate was higher for the control group than the other two groups due to the higher pit ventilation rates. From phase $\mathrm{G} 2$ to $\mathrm{F} 2$, the group phase mean ventilation rates of the three groups was not statistically different $(p>0.05)$.

\subsubsection{Manure volume and $\mathrm{NH}_{4}{ }^{+}-\mathrm{N}$ content}

The accumulated manure volumes throughout the cycle were control $>T_{1}>T_{2}$, though not significantly different ( $p>0.05$, Figure 3 ). They were $46.8,43.7$ and $41.0 \mathrm{~m}^{3}$ for the control, $\mathrm{T}_{1}$ and $\mathrm{T}_{2}$ groups, respectively. This result was consistent with the findings of Portejoie et al. (2004) that the amount of pig slurry decreased as the CP supply was reduced.

\section{[Insert Figure 3 here]}

The $\mathrm{NH}_{4}{ }^{+} \mathrm{N}$ contents in manure were also the highest for the control group and the lowest for the $\mathrm{T}_{2}$ group (Figure 4). The differences among the three groups were statistically significant during all three growth stages $(p<0.05)$. This result agreed with the study of Power et al. (2007) who showed a reduced $\mathrm{NH}_{4}{ }^{+}-\mathrm{N}$ content of the manure from pigs fed with low $\mathrm{CP}$ diet. The reduced $\mathrm{NH}_{4}{ }^{+}-\mathrm{N}$ in manure was

primarily from the reduced urinary N (Canh et al., 1998; Kerr and Easter, 1995; Portejoie et al., 2004)

\section{[Insert Figure 4 here]}

\subsection{Ammonia concentration}

The building phase mean pit $\mathrm{NH}_{3}$ concentrations averaged at $1.4 \pm 0.3 \mathrm{ppm}$ at the beginning (phase N1) and reached $4.9 \pm 3.9$ ppm by the end of the experiment (phase F2). Because the sampling of PLS $\mathrm{NH}_{3}$ concentration at the start of wall fan use from phase $\mathrm{G} 1$, the building phase mean PLS $\mathrm{NH}_{3}$ concentrations were quite constant throughout the experiment: they were $3.3 \pm 1.6 \mathrm{ppm}$ in phase G1, and maintained $3.3 \pm 0.9 \mathrm{ppm}$ in F2. Ammonia concentrations in the PLS were mostly between 50\% and 70\% of those in the pits (Table 4).

Though the $\mathrm{NH}_{3}$ concentrations had been lower and very close in the treated groups during $\mathrm{N} 2$ and $\mathrm{N} 3$, they became statistically different from phase $\mathrm{N} 4(p<0.05)$. The measured group phase mean $\mathrm{NH}_{3}$ 
concentrations both in the pits and PLS followed the order of control $>T_{1}>T_{2}(p<0.05)$. The differences of $\mathrm{NH}_{3}$ concentrations among the pits of the control group were much larger than those in the two treated groups. Because there were no significant differences among the group phase mean pit ventilation rates, higher temperature in the pit of $\mathrm{R} 4\left(24.8^{\circ} \mathrm{C}\right)$ than the temperatures in other rooms $\left(21.0-23.0^{\circ} \mathrm{C}\right)$ could lead to the differences among the four control rooms. Higher pit air temperature positively affected the manure temperature, thus accelerated the bacterial ammonification in the manure (Elliott and Collins, 1982). It could also promote the gaseous $\mathrm{NH}_{3}$ release from liquid manure by influencing the dissociation constant, which determined the amount of $\mathrm{NH}_{3}$ molecular in the manure solution, and Henry's constant, which closely associated with the mass concentration of $\mathrm{NH}_{3}$ at the gas-liquid interface $(\mathrm{Ni}, 1999)$.

[Insert Table 4 here]

\subsection{Ammonia emission}

\subsubsection{Daily differences}

The building cycle mean $\mathrm{NH}_{3}$ emission was $48.5 \mathrm{~g} \mathrm{~d}^{-1} \mathrm{AU}^{-1}$. The highest and the lowest room cycle mean emission rates were $110.1(\mathrm{R} 4)$ and $21.5(\mathrm{R} 7) \mathrm{g} \mathrm{d}^{-1} \mathrm{AU}^{-1}$, respectively. The building daily mean emission rates during the experiment ranged from 3.7 to $186.2 \mathrm{~g} \mathrm{~d}^{-1} \mathrm{AU}^{-1}$.

In the control group, both $\mathrm{R} 4$ and $\mathrm{R} 8$ showed emission rates as high as $150 \mathrm{~g} \mathrm{~d}^{-1} \mathrm{AU}^{-1}$ between $\mathrm{d} 20$ and d 30 (Figure 5). In R4, high emission rates (between 126.7 and $186.2 \mathrm{~g} \mathrm{~d}^{-1} \mathrm{AU}^{-1}$ ) lasted until $\mathrm{d} 65$ and decreased afterward. In R8, it decreased as soon as the highest rate was reached on $\mathrm{d} 25$. The highest emission rates for $\mathrm{R} 1$ and $\mathrm{R} 11$ were 66.9 and $82.1 \mathrm{~g} \mathrm{~d}^{-1} \mathrm{AU}^{-1}$, respectively, which were observed between d 35 and d 90. The differences in the daily emission rates were larger in the control group rooms than in the rooms of two treated groups.

\section{[Insert Figure 5 here]}

For the two treated groups, the highest room daily mean emission rates were observed between $\mathrm{d} 20$ and $\mathrm{d} 30$. In the $\mathrm{T}_{1}$ group, the maximum daily emission rates were from 52.9 to $108.8 \mathrm{~g} \mathrm{~d}^{-1} \mathrm{AU}^{-1}$ for the four rooms; in the $\mathrm{T}_{2}$ group, they ranged from 37.8 to $79.3 \mathrm{~g} \mathrm{~d}^{-1} \mathrm{AU}^{-1}$. At the later stage of the experiment, the room daily mean emission rates of the control rooms still varied substantially within the group, but 
those from the two treated groups converged to similarly low levels (Figure 5).

\subsubsection{Growth stage differences}

During the nursery stage, the amount of $\mathrm{NH}_{3}$ emitted from the control, $\mathrm{T}_{1}$ and $\mathrm{T}_{2}$ group accounted for $29.7 \%, 30.8 \%$, and $36.9 \%$, respectively, of that emitted throughout the respective experimental cycle. During the grower stage, the ratios were $49.2 \%, 48.8 \%$, and $42.5 \%$, respectively. They were $21.1 \%$, $20.4 \%$, and $20.6 \%$, respectively, during the finisher stage. It was consistent in all three groups that nearly half of the emissions were emitted during the grower stage. However, the $\mathrm{T}_{2}$ group emitted more $\mathrm{NH}_{3}$ than the other two groups during the nursery stage.

\section{[Insert Table 5 here]}

The highest group phase mean emission rate was observed at different growth stage for the three groups: It was in the phase $\mathrm{G} 1\left(99.6 \mathrm{~g} \mathrm{~d}^{-1} \mathrm{AU}^{-1}\right)$ for the control group, and in the phase $\mathrm{N} 3$ for the two treated groups. From the phase N3, the group phase mean emissions from $\mathrm{T}_{2}$ were only $34 \%-45 \%$ of those from the control group.

\section{Discussion}

\subsection{Effect of dietary $\mathrm{CP}$ reduction with AA supplementation on cycle mean $\mathrm{NH}_{3}$ emissions}

The total $\mathrm{NH}_{3}$ emitted throughout the experiment were $37.3 \mathrm{~kg}, 25.0 \mathrm{~kg}$, and $16.0 \mathrm{~kg}$ from the control, the $\mathrm{T}_{1}$, and $\mathrm{T}_{2}$ group, respectively. The $\mathrm{NH}_{3}$ emitted from $\mathrm{T}_{1}$, and $\mathrm{T}_{2}$ groups were about $67.0 \%$ and $42.9 \%$ of that from the control group.

The group cycle mean emission from the control group was the highest among all the three groups. It averaged at $68.9 \mathrm{~g} \mathrm{~d}^{-1} \mathrm{AU}^{-1}$, with the daily mean ranged from 4.6 to $186.2 \mathrm{~g} \mathrm{~d}^{-1} \mathrm{AU}^{-1}$. Large differences

among the rooms were found within the control group, with the standard deviation of $40.0 \mathrm{~g} \mathrm{~d}^{-1} \mathrm{AU}^{-1}$. The average emission rates were lower for the $\mathrm{T}_{1}$ and $\mathrm{T}_{2}$ groups, which were $46.7 \pm 19.5$ and $29.8 \pm 10.6 \mathrm{~g} \mathrm{~d}^{-}$ ${ }^{1} \mathrm{AU}^{-1}$, respectively.

A number of dietary factors could account for the discrepancies among groups. On the one hand, the standard diet fed to the pigs of the control group was formulated to meeting the requirement of lysine, the most limiting AA for pig growth, resulting in excessive non-limiting AA. The excessive non-limiting AA 
could be mostly catabolized and excreted from the pigs in the form of urea (Brown and Cline, 1973; Toledo et al., 2014). Zervas et al. (2002) reported that the daily urinary N excretion was linearly correlated with plasma urea. Otherwise, in the two treated groups, according to Panetta (2005b), reduced dietary CP might lead to reduced mass and changed chemical forms of excreted $\mathrm{N}$, as well as the altered ratio of urinary $\mathrm{N}$ to fecal $\mathrm{N}$.

On the other hand, the supplemented crystalline AA was more bioavailable than the AA bounded in the feed ingredients (Figueroa et al., 2002; Toledo et al., 2014). Higher utilization efficiency and less excretion of the supplemented AA could lead to lower $\mathrm{NH}_{3}$ emissions from the $\mathrm{T}_{1}$ and $\mathrm{T}_{2}$ groups.

Also, the CP-reduced diet of the treated groups $\mathrm{T}_{1}$ and $\mathrm{T}_{2}$ were compensated with increased corns, which were a rich source of carbohydrates and supposed to be nearly $100 \%$ digested in the intestine (Otto et al., 2003; Smith et al., 2004). When the intestinal microflora had access to more carbohydrates as fermentation substrate, vigorous microbial synthesis could occur, resulting in increased microbial utilization of dietary $\mathrm{N}$ and excreted $\mathrm{N}$ in the feces. In addition, decreased dietary $\mathrm{CP}$ could lead to reduced urinary pH by promoting the VFA production (Canh et al., 1998a; Otto et al., 2003; Portejoie et al., 2004), and alleviated potential $\mathrm{NH}_{3}$ release.

\subsection{Effect of dietary $\mathrm{CP}$ reduction with $\mathrm{AA}$ supplementation on phase mean $\mathrm{NH}_{3}$ emissions}

The $\mathrm{NH}_{3}$ emissions from the $\mathrm{T}_{1}$ and $\mathrm{T}_{2}$ group were lower than that from the control group, and this effect became statistically significant from the phase N3 $(p<0.05$, Table 5).

During the nursery phases N1-N3, the CP was reduced by $2.1 \%-2.5 \%$ for the $\mathrm{T}_{1}$ and by $4.4-5.0 \%$ for the $\mathrm{T}_{2}$ groups; while the AA was supplied with the approximate ratio 1:3:7 (control: $\mathrm{T}_{1}: \mathrm{T}_{2}$, Table 2). A total of 1.3 and $2.4 \mathrm{~kg} \mathrm{NH}_{3}$ emission was reduced for the $\mathrm{T}_{1}$ and $\mathrm{T}_{2}$ groups, respectively, compared with that emitted from the control group (Table 6). In the phase N4, the reduced CP was $3.7 \%$ and $7.6 \%$, respectively, for the $T_{1}$ and $T_{2}$ groups, and the amino acids were supplied only to the $T_{1}$ and $T_{2}$ groups, with the ratio of $0.3 \%$ and $1.0 \%$, respectively. Throughout phase $\mathrm{N} 4$, the emitted $\mathrm{NH}_{3}$ from the $\mathrm{T}_{1}$ and $\mathrm{T}_{2}$ groups was 2.0 and $2.8 \mathrm{~kg}$ more, respectively, than that from the control group. The overall reduction of $\mathrm{NH}_{3}$ during the nursery stage was $3.3 \mathrm{~kg}$ for the $\mathrm{T}_{1}$ and $5.1 \mathrm{~kg}$ for the $\mathrm{T}_{2}$ groups, compared with the 
control group.

\section{[Insert Table 6 here]}

During the grower stage, the percentages of the reduced dietary $\mathrm{CP}$ were $3.7 \%$ in the $\mathrm{T}_{1}$ and $7.8 \%$ in the $\mathrm{T}_{2}$ groups, and the AA was supplied to the two treated groups only $\left(0.3 \%\right.$ to $\mathrm{T}_{1}$ and $1.0 \%$ to $\mathrm{T}_{2}$, Table 2). The emitted $\mathrm{NH}_{3}$ from the control group decreased substantially, from $7.2 \mathrm{~kg}$ in G1 to $5.0 \mathrm{~kg}$ in G3; but that from the two treated groups were quite constant, about $4.1 \mathrm{~kg}$ per phase from the $\mathrm{T}_{1}$ group and $2.2 \mathrm{~kg}$ per phase from the $\mathrm{T}_{2}$ group (Table 6). The total amount of $\mathrm{NH}_{3}$ emitted from the control, $\mathrm{T}_{1}$ and $\mathrm{T}_{2}$ groups were $18.4,12.2$ and $6.8 \mathrm{~kg}$, respectively, during the grower stage.

During the finisher stage, the emitted $\mathrm{NH}_{3}$ was $7.9,5.1$ and $3.3 \mathrm{~kg}$ from the control, $\mathrm{T}_{1}$, and $\mathrm{T}_{2}$ group, respectively. A total of 2.8 and $4.6 \mathrm{~kg} \mathrm{NH}_{3}$ was reduced for the $\mathrm{T}_{1}$ and $\mathrm{T}_{2}$ group, compared with the control.

\subsection{Non-dietary influencing factors}

Ammonia emission from a confined pig building was mainly influenced by the building ventilation rate and the $\mathrm{NH}_{3}$ release rate at manure surface. The release rate of $\mathrm{NH}_{3}$ was primarily affected by the TAN (total ammoniacal nitrogen) concentration in manure, the mass transfer coefficient, which was dependent on temperature, the air velocity over the manure emitting surface, and the area of emitting surface (Monteny and Erisman, 1998; Philippe et al., 2011).

Though not significantly different, the group cycle mean pit temperature and pit ventilation rate were also the highest for the control group and the lowest for the $\mathrm{T}_{2}$ group. This could contribute to the higher emission rates of the control group and lower of the $\mathrm{T}_{2}$ group.

Pig weights did not demonstrate as a direct influence factor on $\mathrm{NH}_{3}$ emissions in this study. The treatments had little impacts on the group phase mean pig weight and weight gains $(p>0.05)$. In the meanwhile, the temperature and ventilation rate were not likely to be influenced by the heat production of pigs. The total heat production from finishing pigs at $20^{\circ} \mathrm{C}$ was related to the pig weight and the surrounding temperature (CIGR, 2002). In this study, the group phase mean pig weight and room temperature were not significantly different among groups. Therefore, the heat produced by the three 
groups was not expected to cause substantial differences among the groups.

Different levels of manure $\mathrm{NH}_{4}{ }^{+}-\mathrm{N}$ were observed among the three groups $(p<0.05)$ : the highest for the control group, and the lowest for the $\mathrm{T}_{2}$ group. The manure $\mathrm{NH}_{4}{ }^{+}-\mathrm{N}$ of the $\mathrm{T}_{1}$ group corresponded to $16.9 \%, 20.8 \%$ and $15.3 \%$ less than that of the control group, respectively, excreted during the nursery, grower and finisher stages. Pigs in the $\mathrm{T}_{2}$ group corresponded to an $\mathrm{NH}_{4}{ }^{+}-\mathrm{N}$ reduction of $40.3 \%, 45.9 \%$ and $29.6 \%$, respectively. The CP reduced diet in this study resulted in significantly less manure $\mathrm{NH}_{4}{ }^{+}-\mathrm{N}$ contents in the two treated groups. This might have directly lead to less $\mathrm{NH}_{3}$ emissions from the two treated groups.

\section{Conclusions}

The following conclusions were drawn:

1. Reduction of dietary $\mathrm{CP}$ decreased accumulated manure volumes and the manure $\mathrm{NH}_{4}{ }^{+}-\mathrm{N}$ contents. The higher $\mathrm{NH}_{4}{ }^{+}-\mathrm{N}$ concentrations, along with higher pit temperatures and ventilation rates, contributed to the higher $\mathrm{NH}_{3}$ emissions from the control group.

2. The diet $\mathrm{CP}$ reduction with AA supplementation effectively mitigated $\mathrm{NH}_{3}$ emissions. Compared with the control group, $\mathrm{T}_{1}$, and $\mathrm{T}_{2}$ reduced $\mathrm{NH}_{3}$ emissions by $32.2 \%$ and $56.7 \%$, respectively.

3. The peak $\mathrm{NH}_{3}$ emissions were observed in the nursery stage $\mathrm{N} 3$ for the two treated groups, but delayed for the control group in grower stage G1.

\section{Acknowledgements}

The research was funded by the USDA / University of Arkansas project (UA AES 91088-02). This work was also supported by the Agriculture Research Program of College of Agriculture, the Graduate Support of Purdue Research Foundation, and the Bilsland Dissertation Fellowship of Purdue University. The authors thank the assistance of the swine building managers Brian Ford and Katelin Ade during this study.

\section{References}

1. Aarnink, A.J.A., Keen, A., Metz, J.H.M., Speelman, L., Verstegen, M.W.A., 1995. Ammonia emission patterns during the growing periods of pigs housed on partially slatted floors. J. Agric. Eng. 
Res. 62(2), 105-116. http://dx.doi.org/10.1006/jaer.1995.1069.

2. Aarnink, A.J.A., Verstegen, M.W.A., 2007. Nutrition, key factor to reduce environmental load from pig production. Livest. Sci. 109(1-3), 194-203. http://dx.doi.org/10.1016/j.livsci.2007.01.112.

3. Aarnink, A.J.A., Wagemans, M.J.M., 1997. Ammonia volatilization and dust concentration as affected by ventilation systems in houses for fattening pigs. Trans. ASAE. 40(4), 1161-1170.

4. Brown, J.A., Cline, T.R., 1974. Urea excretion in the pig: An indicator of protein quality and amino acid requirements. J. Nutr. 104(5), 542-545.

5. Canh, T.T., Aarnink, A.J.A., Schutte, J.B., Sutton, A., Langhout, D.J., Verstegen, M.W.A., 1998a. Dietary protein affects nitrogen excretion and ammonia emission from slurry of growing-finishing pigs. Livest. Prod. Sci. 56(3), 181-191. http://dx.doi.org/10.1016/S0301-6226(98)00156-0.

6. Canh, T.T., Aarnink, A.J., Verstegen, M.W., Schrama, J.W., 1998b. Influence of dietary factors on the $\mathrm{pH}$ and ammonia emission of slurry from growing-finishing pigs. J. Anim. Sci. 76(4), 1123-1130. http://dx.doi.org/10.2527/1998.7641123x.

7. CIGR, 2002. Climatization of animal houses. Heat and moisture production at animal and house levels., CIGR 4th Report of Work Group on Climatization of animal houses. Horsens, Denmark.

8. Edmonds, M.S., Baker, D.H., 1987. Amino acid excesses for young pigs: Effects of excess methionine, tryptophan, threonine or leucine. J. Anim. Sci. 64(6), 1664-1671. http://dx.doi.org/10.2527/jas1987.6461664x.

9. Elliott, H.A., Collins, N.E., 1982. Factors affecting ammonia release in broiler houses. Trans. ASAE. 25(2), 413-418. http://dx.doi.org/10.13031/2013.33545.

10. EPA, 2009. CERCLA/EPCRA Administrative Reporting Exemption for Air Releases of Hazardous Substances from Animal Waste at Farms. https://www.epa.gov/sites/production/files/201308/documents/cafo_rule_fact_sheet.pdf (accessed 6-2016).

11. Figueroa, J.L., Lewis, A.J., Miller, P.S., Fischer, R.L., Gómez, R.S., Diedrichsen, R.M., 2002. Nitrogen metabolism and growth performance of gilts fed standard corn-soybean meal diets or low- 
crude protein, amino acid-supplemented diets. J. Anim. Sci. 80(11), 2911-2919.

http://dx.doi.org/10.2527/2002.80112911x.

12. Hayes, E.T., Leek, A.B.G., Curran, T.P., Dodd, V.A., Carton, O.T., Beattie, V.E., O’Doherty, J.V., 2004. The influence of diet crude protein level on odour and ammonia emissions from finishing pig houses. Bioresour. Technol. 91(3), 309-315. http://dx.doi.org/10.1016/S0960-8524(03)00184-6.

13. Holden, P.J., Ensminger, M.E., 2006. Swine science, 7th ed. Pearson Education Ltd., New Jersey.

14. Kerr, B.J., Easter, R.A., 1995. Effect of feeding reduced protein, amino acid-supplemented diets on nitrogen and energy balance in grower pigs. J. Anim. Sci. 73(10), 3000-3008. http://dx.doi.org/10.2527/1995.73103000x.

15. Le, P.D., Aarnink, A.J.A., Jongbloed, A.W., van der Peet Schwering, C.M.C., Ogink, N.W.M., Versiegen, M.W.., 2007. Effects of crystalline amino acid supplementation to the diet on odor from pig manure. J. Anim. Sci. 85(3), 791-801. http://dx.doi.org/10.2527/jas.2006-644.

16. Monteny, G.J., Erisman, J.W., 1998. Ammonia emission from dairy cow buildings: A review of measurement techniques, influencing factors. Netherlands J. Agric. Sci. 46(3), 225-247.

17. Nelson, D.W., Sommers, L.E., 1972. A simple digestion procedure for estimation of total nitrogen in soils and sediments. J. Environ. Qual. 1(4), 423-425. http://dx.doi.org/10.2134/jeq1972.00472425000100040020x.

18. Ni, J.-Q., 1999. Mechanistic models of ammonia release from liquid manure: A review. J. Agric. Eng. Res. 72(1), 1-17. http://dx.doi.org/10.1006/jaer.1998.0342.

19. Ni, J.-Q., Diehl, C.A., Liu, S., Lopes, I.M., Radcliffe, J.S., Richert, B., 2015. An innovative ventilation monitoring system at a pig experimental building. In: International Symposium on Animal Environment and Welfare. Beijing, China: China Agriculture Press. pp. 58-65.

20. Ni, J.-Q., Heber, A.J., 2010. An on-site computer system for comprehensive agricultural air quality research. Comput. Electron. Agric. 71(1), 38-49. http://dx.doi.org/10.1016/j.compag.2009.12.001.

21. Ni, J.-Q., Heber, A.J., 2008. Sampling and Measurement of Ammonia at Animal Facilities. Adv. Agron. 98, 201-269. http://dx.doi.org/10.1016/S0065-2113(08)00204-6. 
22. Ni, J.-Q., Kaelin, D., Lopes, I.M., Liu, S., Diehl, C.A., Zong, C., 2016. Design and performance of a direct and continuous ventilation measurement system for variable-speed pit fans in a pig building. Biosyst. Eng. 147, 151-161. http://dx.doi.org/10.1016/j.biosystemseng.2016.04.011.

23. Otto, E.R., Yokoyama, M., Hengemuehle, S., von Bermuth, R.D., van Kempen, T., Trottier, N.L., 2003. Ammonia, volatile fatty acids, phenolics, and odor offensiveness in manure from growing pigs fed diets reduced in protein concentration. J. Anim. Sci. 81(7), 1754-1763. http://dx.doi.org/10.2527/2003.8171754x.

24. Panetta, D.M., Powers, W.J., Xin, H., Kerr, B.J., 2005a. Nitrogen excretion and ammonia emissions from pigs fed reduced crude protein diets or yucca extract. Animal Industry Report: AS 651, ASL R2014. http://lib.dr.iastate.edu/ans_air/vol651/iss1/49 (accessed 11-2016).

25. Panetta, D.M., Powers, W.J., Xin, H., Kerr, B.J., Stalder, K.J., 2005b. Nitrogen excretion and amonia emissions from pigs fed modified diets. J. Environ. Qual. 35(4), 1297-1308. http://dx.doi.org/10.2134/jeq2005.0411.

26. Philippe, F.-X., Cabaraux, J.-F., Nicks, B., 2011. Ammonia emissions from pig houses: Influencing factors and mitigation techniques. Agric. Ecosyst. Environ. 141(3-4), 245-260. http://dx.doi.org/10.1016/j.agee.2011.03.012.

27. Philippe, F.-X., Laitat, M., Canart, B., Farnir, F., Massart, L., Vandenheede, M., Nicks, B., 2006. Effects of a reduction of diet crude protein content on gaseous emissions from deep-litter pens for fattening pigs. Anim. Res. 55(5), 397-407. http://dx.doi.org/10.1051/animres:2006029.

28. Portejoie, S., Dourmad, J.Y., Martinez, J., Lebreton, Y., 2004. Effect of lowering dietary crude protein on nitrogen excretion, manure composition and ammonia emission from fattening pigs. Livest. Prod. Sci. 91(1-2), 45-55. http://dx.doi.org/10.1016/j.livprodsci.2004.06.013.

29. Powers, W.J., Zamzow, S.B., Kerr, B.J., 2007. Reduced crude protein effects on aerial emissions from swine. Appl. Eng. Agric. 23(4), 539-546. http://dx.doi.org/10.13031/2013.23487.

30. Radcliffe, S., Richert, B., Sholly, D., Foster, K., Hollas, B., Lim, T., Ni, J., Heber, A., Sutton, A., 2005. Diet Modification to Reduce Odors, Gas Emissions and Nutrient Excretions from Swine 
Operations. In: Mitigating Air Emissions from Animal Feeding Operations. Des Moines, Iowa, May 19-20, eds, E. Muhlbauer et al. pp. 114-119.

31. Saha, C.K., Ammon, C., Berg, W., Fiedler, M., Loebsin, C., Sanftleben, P., Brunsch, R., Amon, T., 2014. Seasonal and diel variations of ammonia and methane emissions from a naturally ventilated dairy building and the associated factors influencing emissions. Sci. Total Environ. 468-469, 53-62. http://dx.doi.org/10.1016/j.scitotenv.2013.08.015.

32. Smith, L.F., Lemay, S.P., Patience, J.F., Zijlstra, R.T., 2004. Effects of dietary crude protein level and sugar beet pulp inclusion on nitrogen excretion patterns in grower and finisher pigs. Can. J. Anim. Sci. 84(4), 717-720. http://dx.doi.org/10.4141/A04-015.

33. Toledo, J.B., Furlan, A.C., Pozza, P.C., Carraro, J., Moresco, G., Ferreira, S.L., Gallego, A.G., 2014. Reduction of the crude protein content of diets supplemented with essential amino acids for piglets weighing 15 to 30 kilograms. Rev. Bras. Zootec. 43(6), 301-309. http://dx.doi.org/10.1590/S151635982014000600004. 


\section{Figure captions}

Figure 1. East-side view of the swine experimental research building. PLS = pig living space.

Figure 2. Building phase means and standard deviations of temperatures (top) and ventilation rates (bottom) during the entire pig cycle. PLS = pig living space.

Figure 3. Building phase means and standard deviations of pit manure volumes for the three groups.

Figure 4. Manure $\mathrm{NH}_{4}{ }^{+}-\mathrm{N}$ contents for the three groups during three growth stages.

Figure 5. Comparison of daily mean ammonia emission rates from the control (top), T1 (middle), and T2 (bottom). 
Table 1. Overview of the experimental design, and start- and end-of-experiment pigs.

\begin{tabular}{|c|c|c|c|c|c|c|c|c|c|c|c|c|}
\hline \multirow{2}{*}{ Design and pigs } & \multicolumn{12}{|c|}{ Room } \\
\hline & 1 & 2 & 3 & 4 & 5 & 6 & 7 & 8 & 9 & 10 & 11 & 12 \\
\hline Experiment design $^{\mathrm{a}}$ & Ctrl & $\mathrm{T}_{1}$ & $\mathrm{~T}_{2}$ & Ctrl & $\mathrm{T}_{1}$ & $\mathrm{~T}_{2}$ & $\mathrm{~T}_{2}$ & $\mathrm{Ctrl}$ & $\mathrm{T}_{1}$ & $\mathrm{~T}_{1}$ & Ctrl & $\mathrm{T}_{2}$ \\
\hline Start date ${ }^{\mathrm{b}}$ & $2 / 25$ & $2 / 25$ & $2 / 25$ & $2 / 25$ & $2 / 25$ & $2 / 25$ & $3 / 4$ & $3 / 4$ & $3 / 4$ & $3 / 4$ & $3 / 4$ & $3 / 4$ \\
\hline Start pigs (n) & 60 & 60 & 60 & 60 & 60 & 60 & 60 & 60 & 60 & 60 & 60 & 60 \\
\hline Start pig weight $(\mathrm{kg})$ & 5.4 & 5.4 & 5.4 & 7.2 & 7.1 & 7.1 & 5.4 & 5.5 & 5.4 & 6.9 & 6.9 & 6.9 \\
\hline End date & $7 / 23$ & $7 / 23$ & $7 / 23$ & $7 / 16$ & $7 / 16$ & $7 / 16$ & $7 / 30$ & $7 / 30$ & $7 / 30$ & $7 / 23$ & $7 / 23$ & $7 / 23$ \\
\hline Total days $(\mathrm{d})$ & 148 & 148 & 148 & 141 & 141 & 141 & 148 & 148 & 148 & 141 & 141 & 141 \\
\hline End pigs (n) & 58 & 59 & 57 & 57 & 60 & 59 & 60 & 59 & 57 & 58 & 59 & 60 \\
\hline End pig weight $(\mathrm{kg})$ & 130.4 & 131.2 & 126.3 & 129.6 & 129.0 & 124.9 & 126.3 & 128.6 & 128.9 & 127.1 & 127.5 & 122.8 \\
\hline
\end{tabular}

a. Ctrl, $\mathrm{T}_{1}$ and $\mathrm{T}_{2}$ stand for the control group, treated 1 group, and treated 2 group, respectively.

b. Month/date in 2015 .

Table 2. Primary ingredients of the pig diet.

\begin{tabular}{|c|c|c|c|c|c|c|c|}
\hline \multirow{2}{*}{ Stage } & \multirow{2}{*}{$\begin{array}{l}\text { Feeding } \\
\text { phase }^{\text {a }}\end{array}$} & \multicolumn{2}{|c|}{ Date $^{b}$} & \multirow{2}{*}{ Days $(n)^{c}$} & \multicolumn{3}{|c|}{ Main diet ingredient: C/SBM/CP/AA $(\%)^{\mathrm{d}}$} \\
\hline & & R1-R6 & R7-R12 & & Control & Treated 1 & Treated 2 \\
\hline \multirow{4}{*}{ Nursery } & $\mathrm{N} 1$ & $2 / 25-3 / 5$ & $3 / 4-3 / 12$ & 8 & $28.0 / 15.0 / 25.0 / 0.1$ & $31.5 / 15.0 / 22.9 / 0.3$ & $35.2 / 15.0 / 20.6 / 0.7$ \\
\hline & $\mathrm{N} 2$ & $3 / 5-3 / 12$ & $3 / 12-3 / 19$ & 7 & $34.1 / 18.0 / 23.8 / 0.1$ & $37.9 / 18.0 / 21.6 / 0.3$ & 41.8/18.0/19.1/0.7 \\
\hline & $\mathrm{N} 3$ & $3 / 12-3 / 26$ & $3 / 19-4 / 2$ & 14 & $39.5 / 20.0 / 31.2 / 0.1$ & $43.6 / 20.0 / 28.7 / 0.3$ & $47.7 / 20.0 / 26.2 / 0.7$ \\
\hline & $\mathrm{N} 4$ & $3 / 26-4 / 9$ & $4 / 2-4 / 16$ & 14 & $46.1 / 31.1 / 18.6 / 0$ & $56.3 / 21.8 / 14.9 / 0.3$ & $66.9 / 12.0 / 11.0 / 1.0$ \\
\hline \multirow{3}{*}{ Grower } & G1 & $4 / 9-4 / 30$ & $4 / 16-5 / 7$ & 21 & $48.2 / 28.1 / 17.3 / 0$ & $59.1 / 18.3 / 13.5 / 0.3$ & $69.8 / 8.3 / 9.6 / 1.0$ \\
\hline & $\mathrm{G} 2$ & $4 / 30-5 / 21$ & $5 / 7-5 / 28$ & 21 & $47.7 / 25.9 / 16.3 / 0$ & $58.1 / 16.4 / 12.6 / 0.3$ & $69.1 / 6.2 / 8.5 / 1.0$ \\
\hline & G3 & $5 / 21-6 / 11$ & $5 / 28-6 / 18$ & 21 & $49.8 / 23.9 / 15.5 / 0$ & $60.3 / 14.3 / 11.8 / 0.3$ & 71.3/4.1/7.7/1.0 \\
\hline \multirow{2}{*}{ Finisher } & F1 & $6 / 11-7 / 2$ & $6 / 18-7 / 9$ & 21 & $67.9 / 21.6 / 15.5 / 0$ & $76.4 / 13.8 / 12.4 / 0.3$ & $85.3 / 5.5 / 9.1 / 0.9$ \\
\hline & $\mathrm{F} 2$ & 7/2-End & 7/9-End & $13 / 20$ & $60.4 / 29.5 / 18.7 / 0$ & $67.4 / 23.2 / 16.2 / 0.2$ & $74.5 / 16.5 / 13.5 / 0.7$ \\
\hline
\end{tabular}

a. N1-N4 stand for nursery diet phases 1 to 4; G1-G3 for grower diet phases 1 to 3; F1-F2 for finisher diet phases 1 to 2 .

b. Month/date in 2015 .

c. Phase F2 were 13 days for R4-R6 and R10-R12; and 20 days for R1-R3 and R7-R9.

d. C/SBM/CP/AA (\%) stand for yellow dent corn / soybean meal / total crude protein / supplemented amino acid in $\%$ of diet. Total $\mathrm{CP}$ was the sum of the $\mathrm{CP}$ content in all feed ingredients. 
Table 3. Means for ammonia emission rates defined and used in the data analysis.

\begin{tabular}{cccc}
\hline & & Room coverage & \\
\cline { 2 - 4 } Time coverage $^{\text {a }}$ & Individual room & 4-room group & All 12 rooms \\
\hline 2-h or 4-h sample & & Group sample mean & Building sample mean \\
One day & Room daily mean & Group daily mean & Building daily mean \\
One feeding phase & Room phase mean & Group phase mean & Building phase mean \\
One growth stage & Room stage mean & Group stage mean & Building stage mean \\
Entire cycle & Room cycle mean & Group cycle mean & Building cycle mean \\
\hline
\end{tabular}

a. The 2-h or 4-h were approximate air sampling intervals at gas sampling locations before April 19 and after April 19, respectively. They were used to calculate daily means but not directly reported in this paper. Measurements for ventilation calculation and other environmental variables were continuous. Outdoor temperature measurement was not related to room coverage.

Table 4. Group phase mean ammonia concentrations.

\begin{tabular}{|c|c|c|c|c|c|c|c|c|c|}
\hline \multirow{2}{*}{ Stage } & \multirow{2}{*}{ Phase } & \multicolumn{4}{|c|}{ Pit } & \multicolumn{4}{|c|}{ Pig living space } \\
\hline & & Ctrl (ppm) & $\mathrm{T}_{1}(\mathrm{ppm})$ & $\mathrm{T}_{2}(\mathrm{ppm})$ & $p^{\mathrm{a}}$ & Ctrl (ppm) & $\mathrm{T}_{1}(\mathrm{ppm})$ & $\mathrm{T}_{2}(\mathrm{ppm})$ & $p^{\mathrm{a}}$ \\
\hline \multirow{4}{*}{ Nursery } & N1 & $1.4 \pm 0.3$ & $1.4 \pm 0.3$ & $1.4 \pm 0.3$ & 0.45 & & & & \\
\hline & $\mathrm{N} 2$ & $2.0 \pm 0.4$ & $1.8 \pm 0.3$ & $1.8 \pm 0.4$ & 0.20 & & & & \\
\hline & N3 & $3.3 \pm 1.7$ & $2.9 \pm 1.0$ & $2.7 \pm 1.0$ & 0.07 & & & & \\
\hline & N4 & $4.8 \pm 2.2$ & $3.6 \pm 0.9$ & $2.8 \pm 0.7$ & $<0.05$ & & & & \\
\hline \multirow{3}{*}{ Grower } & G1 & $7.1 \pm 3.5$ & $4.2 \pm 1.3$ & $2.8 \pm 0.5$ & $<0.05$ & $4.8 \pm 1.8$ & $2.9 \pm 0.7$ & $2.0 \pm 0.4$ & $<0.05$ \\
\hline & G2 & $6.4 \pm 3.2$ & $4.3 \pm 1.8$ & $2.6 \pm 0.6$ & $<0.05$ & $4.0 \pm 2.2$ & $3.0 \pm 1.3$ & $2.0 \pm 0.5$ & $<0.05$ \\
\hline & G3 & $5.3 \pm 2.7$ & $4.1 \pm 1.6$ & $2.7 \pm 0.6$ & $<0.05$ & $2.8 \pm 0.9$ & $2.4 \pm 0.5$ & $1.8 \pm 0.3$ & $<0.05$ \\
\hline \multirow{2}{*}{ Finisher } & F1 & $5.3 \pm 3.7$ & $3.6 \pm 1.7$ & $2.4 \pm 0.5$ & $<0.05$ & $2.9 \pm 0.9$ & $2.5 \pm 0.4$ & $2.0 \pm 0.3$ & $<0.05$ \\
\hline & F2 & $7.5 \pm 5.5$ & $4.0 \pm 2.2$ & $3.3 \pm 0.8$ & $<0.05$ & $3.9 \pm 1.2$ & $3.3 \pm 0.5$ & $2.7 \pm 0.4$ & $<0.05$ \\
\hline
\end{tabular}

a. $\quad p<0.05$ indicates statistically significant differences among the means of three treated groups. 
Table 5. Comparison of group phase mean $\mathrm{NH}_{3}$ emission rates and standard deviations.

\begin{tabular}{|c|c|c|c|c|c|}
\hline \multirow{2}{*}{ Stage } & \multirow{2}{*}{ Phase } & \multicolumn{3}{|c|}{$\mathrm{NH}_{3}$ emission $\left(\mathrm{g} \mathrm{d}^{-1} \mathrm{AU}^{-1}\right)^{a}$} & \multirow{2}{*}{$p^{\mathrm{b}}$} \\
\hline & & Ctrl & $\mathrm{T}_{1}$ & $T_{2}$ & \\
\hline \multirow{4}{*}{ Nursery } & N1 & $26.3 \pm 13.6$ & $23.5 \pm 7.1$ & $24.9 \pm 7.8$ & 0.613 \\
\hline & $\mathrm{N} 2$ & $41.4 \pm 18.6$ & $33.8 \pm 9.7$ & $31.5 \pm 6.7$ & 0.064 \\
\hline & N3 & $78.2 \pm 51.3$ & $61.4 \pm 26.7$ & $44.1 \pm 15.4$ & $<0.01$ \\
\hline & N4 & $89.5 \pm 46.9$ & $54.5 \pm 20.9$ & $37.5 \pm 7.4$ & $<0.01$ \\
\hline \multirow{3}{*}{ Grower } & G1 & $99.6 \pm 48.8$ & $55.9 \pm 21.5$ & $34.0 \pm 7.2$ & $<0.01$ \\
\hline & $\mathrm{G} 2$ & $80.2 \pm 29.7$ & $53.1 \pm 14.8$ & $28.2 \pm 6.1$ & $<0.01$ \\
\hline & G3 & $59.0 \pm 23.6$ & $47.4 \pm 13.2$ & $26.7 \pm 6.1$ & $<0.01$ \\
\hline \multirow{2}{*}{ Finisher } & F1 & $51.3 \pm 22.9$ & $35.4 \pm 8.3$ & $21.1 \pm 5.8$ & $<0.01$ \\
\hline & $\mathrm{F} 2$ & $58.2 \pm 28.4$ & $34.3 \pm 11.0$ & $24.6 \pm 8.4$ & $<0.01$ \\
\hline Cycle mean & & $68.9 \pm 40.0$ & $46.7 \pm 19.5$ & $29.8 \pm 10.6$ & $<0.01$ \\
\hline
\end{tabular}

a. group phase mean \pm standard deviation

b. $\quad p<0.01$ indicates statistically significant differences among the means of the three groups.

Table 6. Reduced $\mathrm{NH}_{3}$ emissions of the treated groups compared with the control group.

\begin{tabular}{|c|c|c|c|c|c|c|c|c|c|c|}
\hline \multirow{2}{*}{ Stage } & \multirow{2}{*}{ Phase } & \multicolumn{2}{|c|}{ CP diff. (\%) } & \multicolumn{2}{|c|}{ AA diff. $(\%)^{a}$} & \multicolumn{3}{|c|}{ Accum. $\mathrm{NH}_{3}(\mathrm{~kg})^{\mathrm{b}}$} & \multicolumn{2}{|c|}{ Accum. diff. $(\mathrm{kg})^{\mathrm{c}}$} \\
\hline & & $\mathrm{T}_{1}$ & $\mathrm{~T}_{2}$ & $\mathrm{~T}_{1}$ & $\mathrm{~T}_{2}$ & Ctrl. & $\mathrm{T}_{1}$ & $\mathrm{~T}_{2}$ & $\mathrm{~T}_{1}$ & $\mathrm{~T}_{2}$ \\
\hline \multirow{5}{*}{ Nursery } & N1 & 2.1 & 4.4 & 0.2 & 0.5 & $0.66 \pm 0.01$ & $0.47 \pm 0.01$ & $0.60 \pm 0.01$ & 0.19 & 0.06 \\
\hline & $\mathrm{N} 2$ & 2.2 & 4.7 & 0.2 & 0.6 & $1.12 \pm 0.02$ & $0.88 \pm 0.01$ & $0.85 \pm 0.01$ & 0.24 & 0.27 \\
\hline & N3 & 2.5 & 5.0 & 0.2 & 0.6 & $4.38 \pm 0.05$ & $3.44 \pm 0.03$ & $2.38 \pm 0.02$ & 0.94 & 1.99 \\
\hline & N4 & 3.7 & 7.6 & 0.3 & 1.0 & $4.92 \pm 0.05$ & $2.95 \pm 0.02$ & $2.10 \pm 0.01$ & 1.98 & 2.82 \\
\hline & Total & & & & & $11.07 \pm 2.2$ & $7.73 \pm 1.48$ & $5.93 \pm 0.89$ & 3.34 & 5.14 \\
\hline \multirow{4}{*}{ Grower } & G1 & 3.8 & 7.7 & 0.3 & 1.0 & $7.17 \pm 0.05$ & $4.08 \pm 0.02$ & $2.41 \pm 0.01$ & 3.09 & 4.76 \\
\hline & $\mathrm{G} 2$ & 3.7 & 7.8 & 0.3 & 1.0 & $6.25 \pm 0.03$ & $4.14 \pm 0.01$ & $2.14 \pm 0.01$ & 2.11 & 4.11 \\
\hline & G3 & 3.7 & 7.8 & 0.3 & 1.0 & $4.96 \pm 0.02$ & $3.98 \pm 0.01$ & $2.24 \pm 0.01$ & 0.98 & 2.72 \\
\hline & Total & & & & & $18.38 \pm 1.11$ & $12.21 \pm 0.08$ & $6.80 \pm 0.14$ & 6.17 & 11.59 \\
\hline \multirow{3}{*}{ Finisher } & F1 & 3.1 & 6.4 & 0.3 & 0.9 & $4.26 \pm 0.01$ & $2.98 \pm 0.01$ & $1.73 \pm 0.01$ & 1.28 & 2.53 \\
\hline & $\mathrm{F} 2$ & 2.5 & 5.2 & 0.2 & 0.7 & $3.61 \pm 0.03$ & $2.09 \pm 0.01$ & $1.52 \pm 0.01$ & 1.52 & 2.09 \\
\hline & Total & & & & & $7.87 \pm 0.46$ & $5.07 \pm 0.63$ & $3.26 \pm 0.15$ & 2.80 & 4.61 \\
\hline \multicolumn{2}{|c|}{ Cycle total } & & & & & $37.33 \pm 2.14$ & $25.01 \pm 1.37$ & $15.98 \pm 0.67$ & 12.32 & 21.35 \\
\hline
\end{tabular}

a. CP diff. and AA diff. are crude protein difference and amino acid difference, respectively, between the control and the specific treated group.

b. Accum. $\mathrm{NH}_{3}$ is accumulative $\mathrm{NH}_{3}$ mass. Mean \pm standard deviation.

c. Accum. diff. is differences of accumulative $\mathrm{NH}_{3}$ mass between the control group and the specific treated group. 


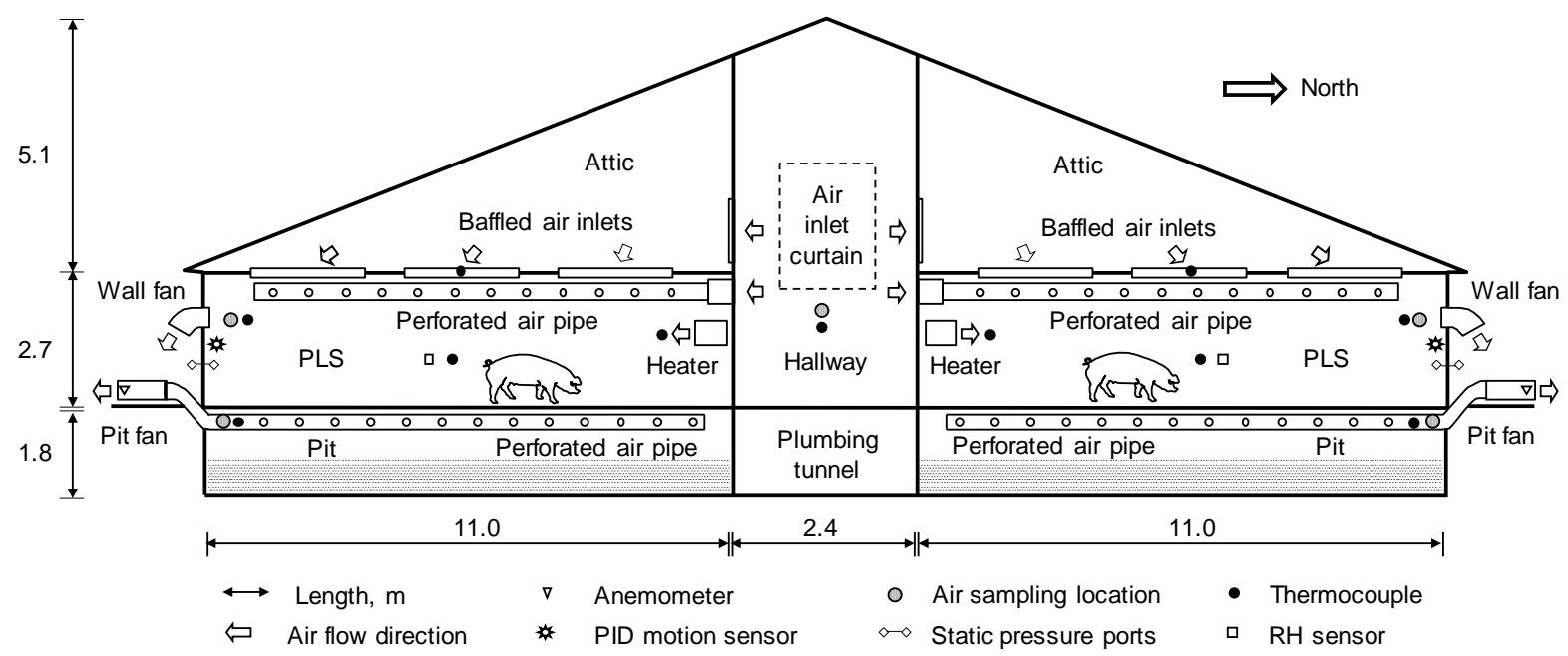

Figure 1. East-side view of the swine experimental research building. PLS = pig living space.
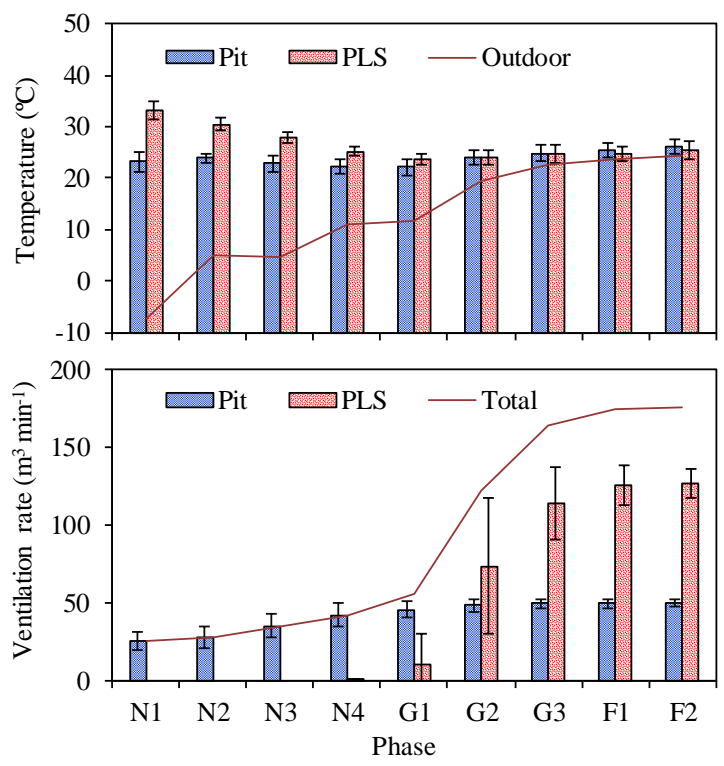

Figure 2. Building phase means and standard deviations of temperatures (top) and ventilation rates (bottom) during the entire pig cycle. PLS = pig living space. 


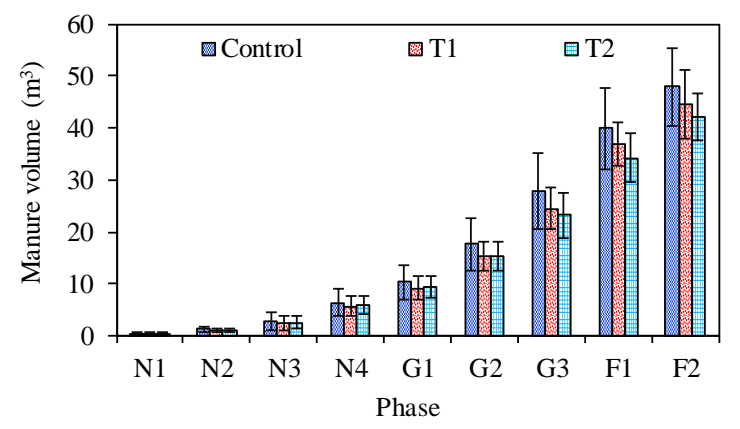

Figure 3. Building phase means and standard deviations of pit manure volumes for the three groups.

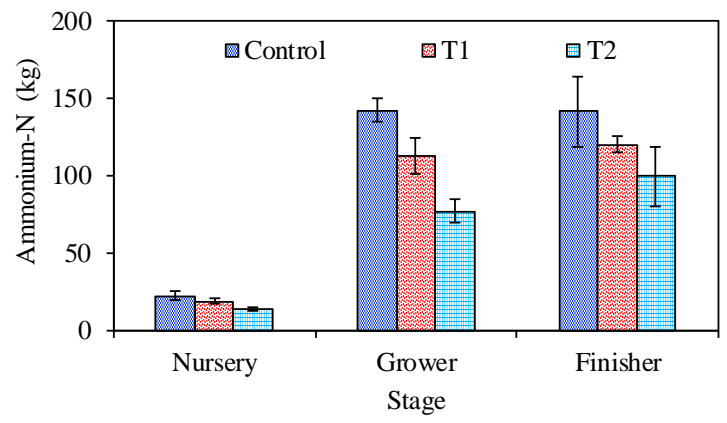

Figure 4. Manure $\mathrm{NH}_{4}{ }^{+}-\mathrm{N}$ contents for the three groups during three growth stages. 

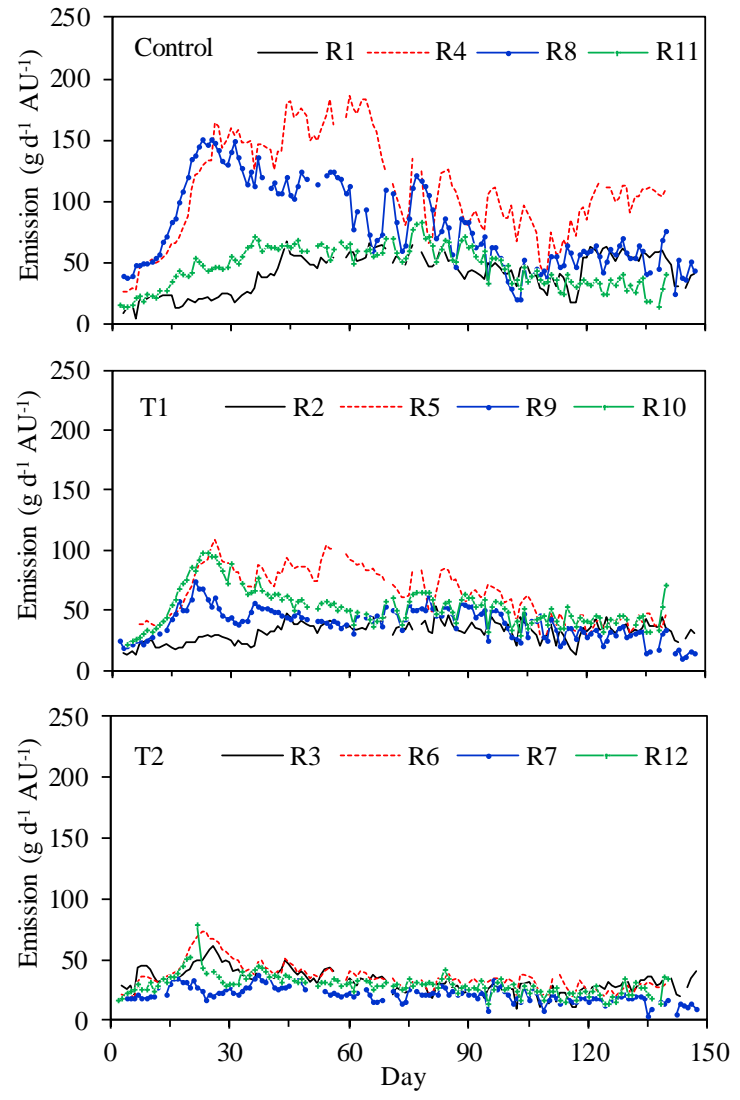

Figure 5. Comparison of daily mean ammonia emission rates from the control (top), $\mathrm{T}_{1}$ (middle), and $\mathrm{T}_{2}$ (bottom). 